\title{
Pembuatan Alat Pemberi Pakan Ikan Dan Pengontrol PH Otomatis
}

\author{
Bearly Ananta Firdaus, Rinta Kridalukmana, Eko Didik Widianto \\ Program Studi Sistem Komputer Fakultas Teknik Universitas Diponegoro \\ Jalan Prof. Sudharto, Tembalang, Semarang, Indonesia \\ bearly.ananta@gmail.com
}

\begin{abstract}
Abstrak - Di dunia yang semakin pesat perkembangannya, proses otomasisasi sudah menjadi hal yang umum. Otomatisasi sering digunakan untuk menghemat tenaga dan untuk pengurangan tingkat kesalahan yang disebabkan oleh manusia. Begitu juga halnya dalam kasus pada kolam ikan yang tidak setiap waktu dapat kita tinjau dari segi perawatan kolam dan pemberian pakan. masalah seperti ini dapat merugikan peternak ataupun penggemar ikan yang sibuk dan tidak mempunyai waktu untuk perawatan kolam. Dalam proses pelaksanaannya, hampir semua pemberian pakan ikan masih diisi secara manual, begitu halnya dengan pengontrolan kadar $\mathbf{P H}$ yang dilakukan dengan takaran yang tidak sesuai. Sehingga perlu adanya pembuatan alat pemberi pakan ikan dan pengtrol PH secara otomatis. Pembuatan alat ini, bertujuan untuk mempermudah pemilik ikan dalam melakukan pemberian pakan, serta membantu dalam pengontrolan $\mathbf{P H}$ kolam. Alat ini juga dilengkapi dengan LCD yang menunjukkan setiap beberapa jam akan dilakukan pemberian pakan dan index PH kolam saat ini..
\end{abstract}

Kata kunci : ATMega, PH, Otomatis, Pakan ikan.

\section{PENDAHULUAN}

$\mathrm{P}$ ada suatu penangkaran ikan, pemberian pakan ikan adalah suatu kegiatan yang rutin dilakukan. Begitu juga dengan pengontrolan kolam yang sebaiknya dilakukan secara rutin untuk pembuatan benih ikan yang baik. Pengontrolan kolam dilakukan untuk mengkondisikan lingkungan yang baik bagi pertumbuhan ikan air tawar dengan kadar PH antara 6,5 - 8,5.

Masih sebagian besar dari penangkaran masih menggunakan proses manual untuk pemberian pakan ikan, dan untuk pengukuran kadar $\mathrm{PH}$ pada kolam masih sangat jarang dilakukan secara rutin. Pengukuran kadar PH yang biasa dilakukan oleh pemilik ikan dengan cara pengambilan sampel air dengan kertas lakmus dan membandingkan hasil warna dengan skala yang sudah ditentukan. Proses manual ini tentu saja memiliki kelemahan utama yaitu kelalaian manusia yang dapat berpengaruh terhadap ikan contohnya lupanya pemberian pakan ikan atau malasnya pengontrolan $\mathrm{PH}$ kolam yang dapat mengakibatkan stress pada ikan.

Dengan kemajuan teknologi sekarang membantu memudahkan manusia khusunya untuk perawatan kolam ikan dengan cara sistem otomatisisasi untuk pemberian pakan ikan dan pengontrolan $\mathrm{PH}$ kolam ikan menggunakan timer pada mikrokontroler dan sensor PH.

Alat Pemberi Pakan Ikan dan Pengontrol PH Otomatis ini dapat membuat tingkat keasaman kolam stabil dari pengaruh lingkungan di dalam kolam. Alat ini juga dapat memberikan pakan ikan secara periodik dari senggang waktu yang sudah ditetapkan sehingga dapat memudahkan pemilik ikan untuk merawat ikan.

\section{METODE PENELITIAN}

Metode yang digunakan pada pembuatan alat pemberi pakan ikan dan pengontrol $\mathrm{PH}$ otomatis ini adalah metode waterfall. Metode Waterfall terdiri dari Analisa kebutuhan (Requirement), perancangan (Design), implementasi (Implementation), dan pengujian (Testing).

Tahap pertama yang dilakukan adalah spesifikasi kebutuhan, yang bertujuan untuk mengetahui apasaja yang dibutuhkan dalam sistem.

Tahap kedua adalah perancangan. Tahapan ini dimaksudkan untuk melakukan perancangan perangkat keras dan perangkat lunak yang akan ditanamkan ke mikrokontroler.

Setelah melewati tahap perancangan, pada tahap ketiga, hasil dari rancangan yang sudah ada tersebut diimplementasikan ke dalam perangkat sehingga terbentuklah suatu perangkat jadi yang siap pakai.

Tahap keempat adalah pengujian.. Pengujian dilakukan terhadap sistem untuk mengidentifikasikan sekaligus memperbaiki kesalahan-kesalahan yang ada. Hasil dari tahapan ini adalah aplikasi yang sudah terbebas dari kesalahankesalahan, dapat berjalan sesuai dengan fungsinya, dan siap digunakan.

\section{HASIL DAN PENGUJIAN}

\subsection{Identifikasi Kebutuhan Sistem}

Proses ini dibutuhkan untuk melakukan proses identifikasi dan proses analisa kebutuhan-kebutuhan yang diperlukan untuk membuat sistem. Kebutuhan-kebutuhan tersebut terdiri atas kebutuhan fungsional dan non-fungsional, yang dijelaskan sebagai berikut.

\subsubsection{Kebutuhan Fungsional}

Kebutuhan fungsional mendeskripsikan fungsi dan layanan dari sebuah sistem. Kebutuhan fungsional dalam perancangan sistem adalah sebagai berikut:

1. Sistem mampu membaca masukan analog dari sensor PH dan mengubah menjadi sinyal digital.

2. Pengguna mampu memberikan masukan waktu dan batas $\mathrm{PH}$ yang diinginkan ke sistem, sehingga pengguna dapat mengatur kapan pakan ikan akan diberikan dan berapa PH kolam yang di inginkan. 
3. Sistem mampu mengolah data masukan dari sensor dan mengirim keluaran kepada LCD, sehingga pengguna dapat memantau waktu pakan ikan dan PH air sekarang.

4. Sistem mampu menghidup dan mematikan keluaran yang berupa motor stepper berdasarkan data yang sudah diolah oleh mikrokontroler.

5. Pengguna mampu memberi masukan secara manual untuk mengaktifkan pemberian pakan ikan seketika.

\subsubsection{Kebutuhan Non-Fungsional}

Kebutuhan non-fungsional mendeskripsikan tingkatan dari kualtias misalnya dapat digunakan atau tidak. Kebutuhan non-fungsional perancangan sistem adalah sebagai berikut:

1. Purwarupa sistem membutuhkan catu daya sebesar 12 Volt.

2. Purwarupa sistem membutuhkan dimensi media berukuran minimal $30 \mathrm{~cm}$ x $15 \mathrm{~cm}$ x $20 \mathrm{~cm}$.

\subsection{Perancangan Perangkat Keras}

Perancangan perangkat keras pada sistem pemberi pakan ikan dan pengontrol PH otomatis ini menggunakan beberapa macam peripheral yang terhubung langsung dengan mikrokontroler sebagai pusat pengolahan data yang berkaitan dengan input atau output sistem. Gambar 2 berikut menunjukkan diagram blok dari sistem pemberi pakan ikan dan pengontrol $\mathrm{PH}$ otomatis.

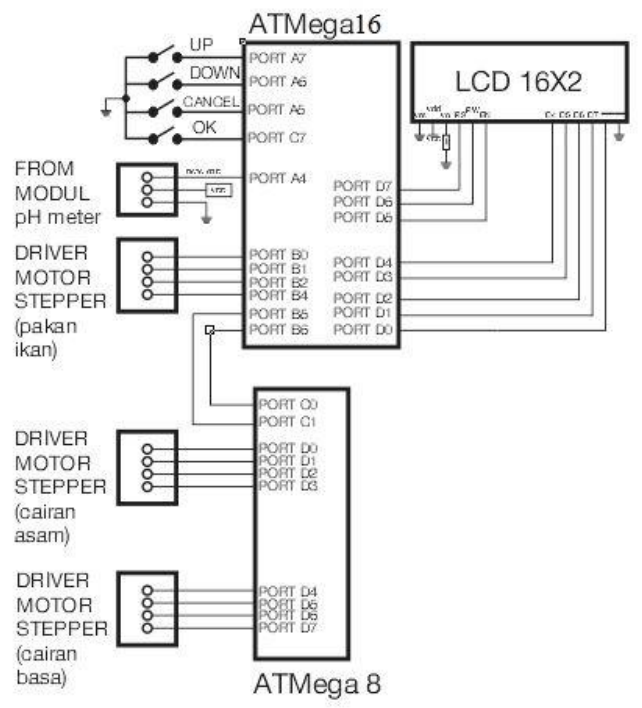

Gambar 1. Blok diagram sistem alat pemberi pakan ikan dan pengontrol $\mathrm{PH}$ otomatis

\subsection{Perancangan Perangkat Lunak}

Perancangan perangkat lunak merupakan perancangan program yang dibutuhkan oleh mikrokontroller ATMega16 untuk dapat mengendalikan output motor stepper sesuai data masukan dari sensor PH dan timer pada mikrokontroler serta dapat menampilkan nilai data dari sensor tersebut di LCD.

Perancangan dan pembuatan perangkat lunak secara umum dapat dijelaskan pada diagram alir proses di Gambar 3.

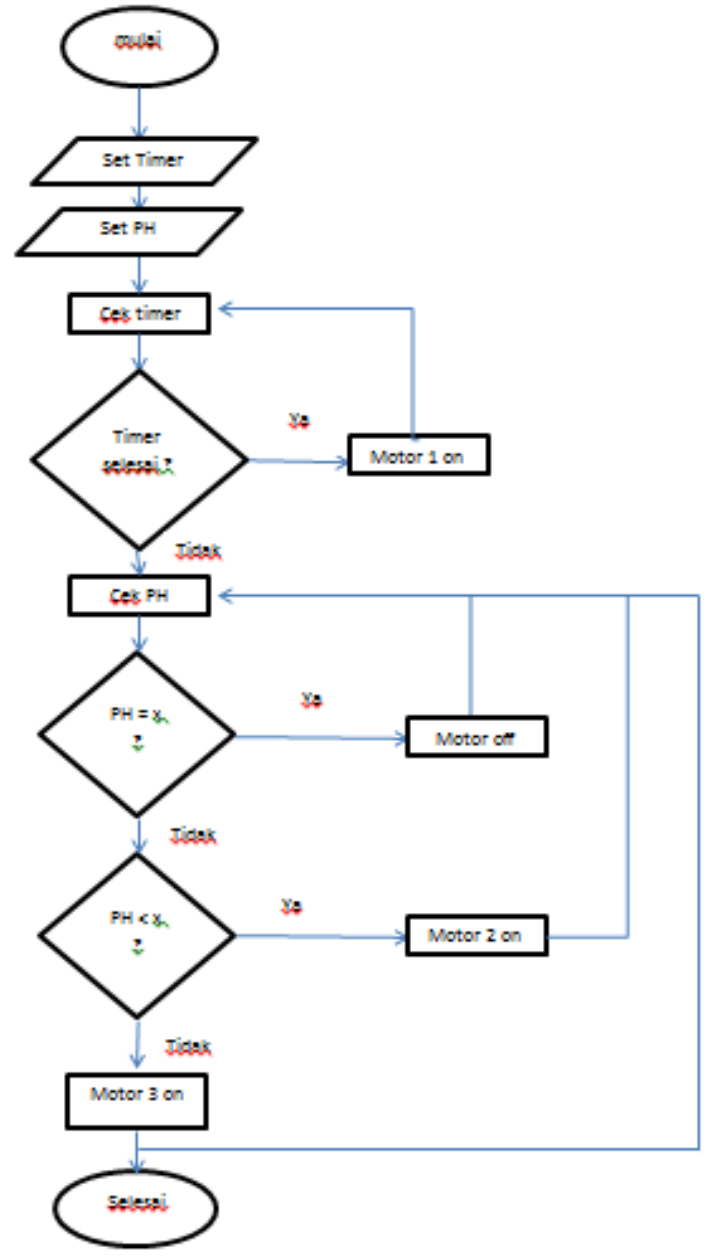

Gambar 2. Diagram Alir Kerja Sistem

Gambar 3 menunjukkan diagram alir dari sistem. Dalam diagram ini yang dilakukan pertama adalah pemberian set timer dan set PH yang diinginkan. Lalu Sistem akan memulai proses penghitungan mundur timer yang akan dilanjutkan oleh pengaktifan motor 1 ( motor pakan ikan ) selama waktu yang ditentukan dan kembali memulai penghitungan mundur. Proses selanjutnya yaitu pengukuran $\mathrm{PH}$ yang dideteksi oleh sensor PH. Pertama - tama sistem akan melakukan pengecekan apakah PH air sudah sesuai dengan yang sudah ditentukan. Apabila ternyata PH lebih rendah daripada yang diinginkan maka motor 2 akan aktif ( motor cairan basa) dan akan kembali melakukan pengecekan PH. Begitu juga halnya apabila PH air lebih tinggi daripada yang diinginkan, maka motor 3 akan aktif ( cairan asam ) dan akan kembali melakukan pengecekan PH. Proses ini dilakukan sampai air mencapai PH yang sudah ditentukan pada saat proses pemberian set $\mathrm{PH}$. Proses perancangan perangkat lunak ditunjukkan oleh gambar 3 . 


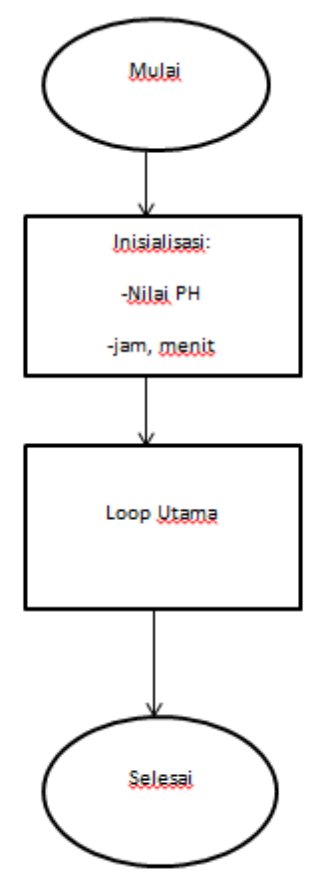

Gambar 3. Diagram Alir Perancangan Perangkat Lunak

Gambar 4 merupakan gambar dari perancangan diagram alir untuk program secara umum. Pada gambar tersebut yang pertama dilakukan adalah inisialiasi untuk nilai integer jam dan menit. Proses selanjutnya yaitu proses penghitungan mundur dari timer yang akan mengaktifkan motor 1 saat mencapai kondisi 0. Proses selanjutnya adalah Loop Utama. Dalam proses ini, nanti akan menampilkan perintah-perintah yang akan dieksekusi secara berulang-ulang.

\subsubsection{Perancangan Menu}

Dalam perancangan perangkat lunak ini dibutuhkan sebuah tampilan utama dan tampilan menu yang berisi tentang pilihan untuk mengatur timer dari pakan ikan dan pengaturan untuk PH kolam yang diinginkan. Gambar 5 berikut menunjukkan diagram alirnya.

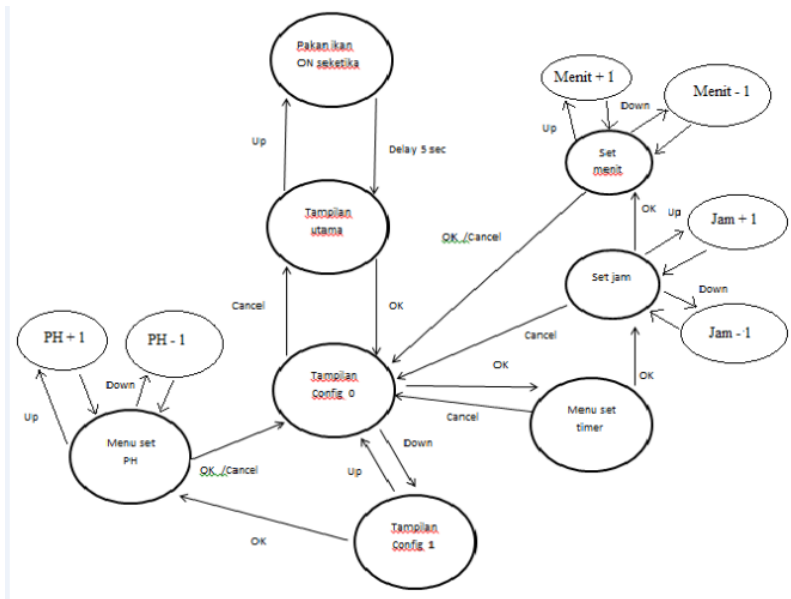

Gambar 4. Diagram alir tampilan menu

Gambar 5 menunjukkan tentang diagram alir dari tampilan menu pada sistem. Untuk beralih ke tampilan menu dari tampilan utama dengan cara menekan tombol OK. Setelah masuk ke tampilan menu / config maka akan terlihat dua pilihan pengaturan yaitu pilihan konfigurasi timer dan pilihan konfigurasi batas PH. Jika sudah selesai memberikan pengaturan kepada timer atau $\mathrm{PH}$ tekan OK untuk kembali ke

Jurnal Teknologi dan Sistem Komputer, Vol.4, No.1, Januari 2016 (e-ISSN: 2338-0403) tampilan menu dan tekan Cancel untuk kembali ke tampilan utama. Dalam tampilan utama terdapat fitur Feed now atau beri pakan ikan sekarang dengan cara menekan tombol UP.

\subsection{Implementasi}

Implementasi sistem terdiri dari keseluruhan perangkat keras yang dirangkai untuk proses sistem pemberi pakan ikan dan pengontrol ph otomatis. Sistem yang terdapat pada gambar 6 terdiri dari sistem minimum ATMega16, perangkat masukan yang berupa sensor PH. LCD $16 \times 2$ berfungsi untuk menampilkan nilai data dari sensor, motor stepper berfungsi untuk mengendalikan penutup pakan ikan, cairan asam dan basa.

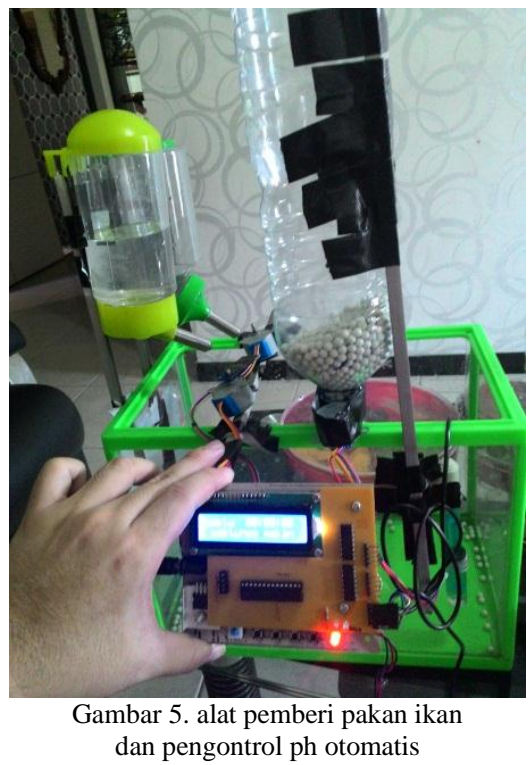

\subsection{Rencana Pengujian Sistem}

Rencana pengujian sistem ini dimulai dengan membuat aquarium yang telah terpasang sistem pemberi pakan ikan dan pengontrol PH otomatis. Pengujian sistem dimulai dari pengukuran perangkat input, perangkat output, dan pengujian kerja sistem.

\subsubsection{Skenario Pengujian}

Terdapat tiga skenario yang akan dilakukan dalam pengujian yang masing-masing mencakup skenario pengujian sub sistem sub sistem perangkat input, sub sistem perangkat output dan sistem secara keseluruhan.

\section{A. Subsistem Perangkat Input}

Pengujian subsitem perangkat input merupakan pengujian perangkat yang digunakan dengan sebagai masukan pada sistem pemberi pakan ikan dan pengontrol $\mathrm{PH}$ otomatis. Perangkat input pada sistem ini terdiri dari sensor $\mathrm{PH}$ dan push button.

\section{B. Subsistem Perangkat Output}

Pengujian subsistem perangkat output adalah pengujian motor stepper dan LCD yang menjadi output dari sistem yang terhubung ke peralatan elektronik. Pengujian subsistem perangkat output bertujuan untuk mengetahui apakah perangkat output yang berupa motor stepper dan LCD dapat bekerja dengan baik atau tidak.

\section{Pengujian Kerja Sistem}

Pengujian kerja sistem adalah pengujian dari alat pemberi pakan ikan dan pengontrol $\mathrm{PH}$ otomatis secara menyeluruh. Pengujian ini menggunakan variabel - 
variabel yang sudah ditetapkan seperti volume air. Pengujian ini juga dimaksudkan untuk mengetahui kisaran waktu yang diperlukan untuk kenaikan atau penurunan $\mathrm{PH}$ dan kisaran jumlah pakan ikan yang dikeluarkan.

\subsection{Pengujian Sistem}

\subsubsection{Pengujian Subsistem Perangkat Input}

Pengujian subsistem perangkat input adalah pengujian perangkat yang menjadi input dari sistem pemberi pakan ikan dan pengontrol PH otomatis. Perangkat input pada sistem ini adalah sensor $\mathrm{PH}$.

Pengujian sensor PH bertujuan untuk mengetahui tingkat keakuratan dari sensor untuk pembacaan tingkat keasaman pada cairan. Pengujian dilakukan dengan menghubungkan sensor PH ke PORT A.4 mikrokontroller dan membandingkannya dengan hasil pembacaan $\mathrm{PH}$ secara manual. Outputnya berupa LCD untuk menampilkan display tingkat keasaman PH. Jika hasil yang terbaca oleh sensor masih berbeda dengan hasil yang dilakukan secara manual maka harus dilakukan kaliberasi ulang, jika kedua hasil sudah menunjukkan hasil yang sama maka sensor sudah bekerja dengan baik. Percobaan dilakukan dari PH 1 - 14 dan hasilnya seperti yang ditunjukan pada Tabel 1 .

Tabel 1. Pengujian Sensor PH

\begin{tabular}{|c|c|c|c|}
\hline NO & Hasil sensor PH & Hasil manual & ADC \\
\hline 1. & 1 & 1 & $1-55$ \\
\hline 2. & 2 & 2 & $56-112$ \\
\hline 3. & 3 & 3 & $113-168$ \\
\hline 4. & 4 & 4 & $169-224$ \\
\hline 5. & 5 & 5 & $225-280$ \\
\hline 6. & 6 & 6 & $261-336$ \\
\hline 7. & 7 & 7 & $337-392$ \\
\hline 8. & 8 & 8 & $393-448$ \\
\hline 9. & 9 & 9 & $449-504$ \\
\hline 10. & 10 & 10 & $505-560$ \\
\hline 11. & 11 & 11 & $561-616$ \\
\hline 12. & 12 & 12 & $617-672$ \\
\hline 13. & 13 & 13 & $673-728$ \\
\hline 14. & 14 & & $729-784$ \\
\hline
\end{tabular}

Hasil pengujian yang ditunjukkan tabel 4.1 menunjukan bahwa sensor $\mathrm{PH}$ sudah mampu mendeteksi tingkat keasaman dengan baik dalam PH 114.

\subsubsection{Pengujian Subsistem Perangkat Output}

Pengujian subsistem perangkat output pada sistem ini adalah pengujian motor stepper dan LCD. Pengujian bertujuan untuk memastikan bahwa motor stepper dan LCD dapat bekerja dengan baik.

\section{A. Pengujian Motor Stepper}

Pengujian dilakukan dengan memprogram mikrokontroller untuk mengendalikan motor stepper dalam kondisi berputar 90 derajat lalu kembali ke posisi awal setelah delay 5 detik. Berikut merupakan listing program untuk mengendalikan kontak relay yang terhubung ke PORT D 0-3 mikrokontroller.

Dari program yang sudah diberikan motor akan berputar sebesar 90 derajat yang ditunjukan gambar 7. kemudian setelah 5 detik maka motor akan kembali berputar 90 derajat ke arah sebaliknya seperti yang ditunjukan gambar 8. Untuk motor yang mengatur cairan $\mathrm{PH}$ akan berulang terus seperti proses diatas sampai $\mathrm{PH}$ yang terdeteksi sensor menjadi seperti yang di inginkan.

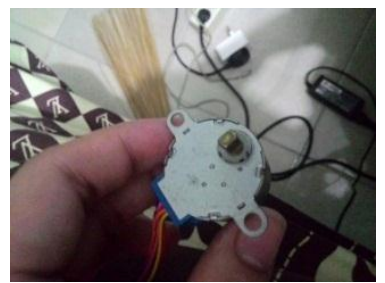

Gambar 6. kondisi saat motor berputar 90 derajat

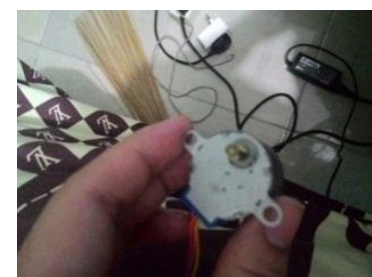

Gambar 7. kondisi saat motor kembali ke awa

\section{B. Pengujian LCD}

Pengujian subsistem LCD 16x2 dilakukan dengan memprogram untuk menampilkan tulisan atau karakter pada LCD, kemudian mencocokan dengan tampilan karakter pada layar LCD.

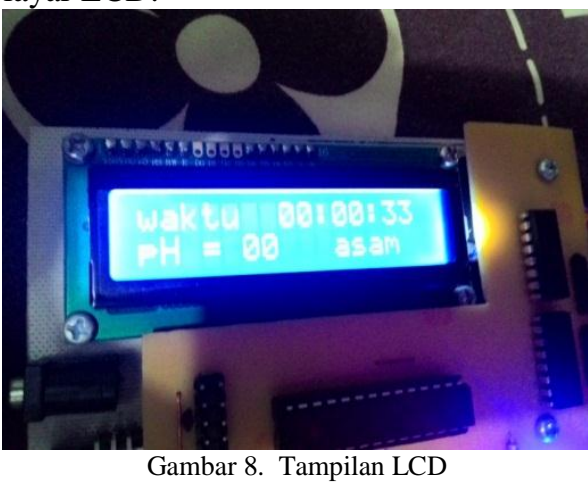

\subsubsection{Pengujian Kerja Sistem}

Pengujian kerja sistem dilakukan untuk menunjukkan apakah keseluruhan sistem telah dapat bekerja sesuai dengan yang diinginkan. Pengujian ini terdiri atas pengujian terhadap fungsi-fungsi dari sistem. Hasil pengujian kerja sistem disajikan pada Tabel 2. sebagai berikut. 
Tabel 2. Hasil pengujian sistem

\begin{tabular}{|c|c|c|c|}
\hline No & Parameter & Pengamatan & Keterangan \\
\hline 1. & $\begin{array}{l}\text { Sistem pertama kali } \\
\text { diaktifkan, LCD } \\
\text { menyala dan } \\
\text { menampilkan waktu } \\
\text { hitung mundur } \\
\text { untuk pemberian } \\
\text { pakan ikan dan } \\
\text { kondisi PH air } \\
\text { sekarang. }\end{array}$ & $\begin{array}{c}\text { LCD } \\
\text { menampilkan } \\
\text { hitungan } \\
\text { mundur untuk } \\
\text { pakan ikan dan } \\
\text { nilai PH air. }\end{array}$ & Berhasil \\
\hline 2. & $\begin{array}{l}\text { Pemberian waktu } \\
\text { untuk pemberian } \\
\text { pakan ikan dan batas } \\
\text { PH yang baru. }\end{array}$ & $\begin{array}{c}\text { Waktu } \\
\text { pemberian } \\
\text { pakan ikan dan } \\
\text { batas } \mathrm{PH} \\
\text { berubah ketika } \\
\text { diganti } \\
\text { pengaturannya. }\end{array}$ & Berhasil \\
\hline 3. & $\begin{array}{l}\text { Mengeluarkan } \\
\text { pakan ikan dengan } \\
\text { menggunakan waktu } \\
\text { mundur yang sudah } \\
\text { ditetapkan. }\end{array}$ & $\begin{array}{l}\text { Motor aktif dan } \\
\text { mengeluarkan } \\
\text { pakan ikan } \\
\text { ketika waktu } \\
\text { hitung mundur } \\
\text { habis. }\end{array}$ & Berhasil \\
\hline $4 .$. & $\begin{array}{l}\text { Mengeluarkan } \\
\text { carian asam ketika } \\
\text { kondisi PH sekarang } \\
\text { lebih tinggi daripada } \\
\text { batas yang sudah } \\
\text { ditentukan. }\end{array}$ & $\begin{array}{l}\text { Motor aktif dan } \\
\text { mengeluarkan } \\
\text { cairan asam. }\end{array}$ & Berhasil \\
\hline 5. & $\begin{array}{l}\text { Mengeluarkan } \\
\text { carian basa ketika } \\
\text { kondisi PH sekarang } \\
\text { lebih rendah } \\
\text { daripada batas yang } \\
\text { sudah ditentukan. }\end{array}$ & $\begin{array}{l}\text { Motor aktif dan } \\
\text { mengeluarkan } \\
\text { cairan basa. }\end{array}$ & Berhasil \\
\hline 6. & $\begin{array}{l}\text { Menghentikan } \\
\text { motor untuk } \\
\text { keluaran cairan } \\
\text { asam / basa ketika } \\
\text { kondisi PH sudah } \\
\text { sesuai dengan yang } \\
\text { ditetapkan. }\end{array}$ & $\begin{array}{l}\text { Motor berhenti } \\
\text { bergerak dan } \\
\text { berhenti } \\
\text { mengeluarkan } \\
\text { cairan ketika } \\
\text { PH sudah sama } \\
\text { dengan yang } \\
\text { sudah } \\
\text { ditetapkan. }\end{array}$ & Berhasil \\
\hline 7. & $\begin{array}{l}\text { Mengeluarkan } \\
\text { pakan ikan dengan } \\
\text { menggunakan fitur } \\
\text { feed now. }\end{array}$ & $\begin{array}{c}\text { Motor bergerak } \\
\text { dan } \\
\text { mengeluarkan } \\
\text { pakan ikan } \\
\text { setelahah push } \\
\text { button up } \\
\text { ditekan. }\end{array}$ & Berhasil \\
\hline
\end{tabular}

Pada pengujian kerja sistem ini digunakan volume air sebanyak 4,950 liter sebagai variabel tetap. Dan setelah melakukan pengujian sebanyak 5 kali telah didapatkan data seperti lama waktu yang dibutuhkan untuk menurun / menaikkan PH, jumlah pakan ikan yang dikeluarkan ( menggunakan replika) dan kecepatan tetesan cairan yang dikeluarkan. Hasil pengujian disajikan pada Tabel 3 sebagai berikut.

Tabel 3. Hasil pengujian

\begin{tabular}{|c|c|c|c|}
\hline No. & $\begin{array}{c}\text { Waktu } \\
\text { penurunan PH 8 } \\
-\mathbf{7}\end{array}$ & $\begin{array}{c}\text { Waktu } \\
\text { penaikan PH } \\
\mathbf{6}-\mathbf{7}\end{array}$ & $\begin{array}{c}\text { Pakan ikan } \\
\text { jatuh }\end{array}$ \\
\hline 1. & 48 menit & 55 menit & 29 \\
\hline 2. & 54 menit & 62 menit & 26 \\
\hline 3. & 66 menit & 78 menit & 23 \\
\hline 4. & 72 menit & 71 menit & 34 \\
\hline 5. & 58 menit & 68 menit & 36 \\
\hline
\end{tabular}

Setelah didapatkan hasil pengujian seperti pada tabel 3 data akan dirata - rata agar mendapatkan hasil yang lebih akurat. Tabel 4 menunjukkan rata - rata dari hasil pengujian.

Tabel 4. Rata - rata hasil pengujian

\begin{tabular}{|c|c|c|}
\hline No. & Parameter & Keterangan \\
\hline 1. & Rata - rata jumlah pakan ikan & 29 butir \\
\hline 2. & Rata - rata penaikan 1 tingkat $\mathrm{PH}$ & 66 menit \\
\hline 3. & Rata - rata penurunan 1 tingkat PH & 59 menit \\
\hline
\end{tabular}

\section{KESIMPULAN DAN SARAN}

Berdasarkan hasil pengujian dan analisis alat pemberi pakan ikan dan pengontrol PH otomatis dapat disimpulkan halhal sebagai berikut.

1. Sistem dapat mendeteksi tingkat keasaman pada air dan menampilkan nilai data sensor pada LCD.

2. Sensor $\mathrm{PH}$ dapat mengukur tingkat keasaman secara akurat dengan perbandingan pengukuran secara manual.

3. Pengguna dapat mengubah masukan waktu untuk pakan ikan dan batas $\mathrm{PH}$.

4. Dibutuhkan mikrokontoler tambahan sebagai driver motor untuk membantu dalam kinerja motor stepper di sistem ini.

5. Sistem dapat mengeluarkan pakan ikan dengan 2 cara yaitu dengan menggunakan waktu hitungan mundur dan pemberian pakan ikan seketika.

Berdasarkan hasil pengujian yang dilakukan pada sistem alat pemberi pakan ikan dan pengontrol PH otomatis, dapat diberikan beberapa saran sebagai berikut.

1. Sistem dapat dikembangkan dalam proses pengontrolan $\mathrm{PH}$ air sehingga dapat lebih cepat stabil.

2. Untuk pemberian pakan ikan dapat digunakan logika fuzzy sehingga sistem dapat mengeluarkan pakan ikan sesuai dengan banyaknya ikan.

3. Dalam pengembangan penelitian sistem kedepannya dapat menggunakan peripheral output yang lebih baik contohnya motor servo atau solenoid valve.

4. Dalam pengembangan penelitian sistem kedepannya dapat ditambahkan catu daya cadangan sehingga tidak terjadi kegagalan sistem saat catu daya utama terputus. 


\section{DAFTAR PUSTAKA}

[1] Syauki, Alfi. 2009. Kelangsungan Hidup Benih Bawal Air Tawar Colossamma Macropomum Cuvier Pada Sistem Pengangkutan Tertutup Dengan Padat Penebaran 43, 86 dan 129 Ekor/Liter. Institut Pertanian Bogor, Bogor.

[2] Rantelino, Alan Prasetyo. 2014. Sistem Pembukaan Kunci Automatis Menggunakan Identifikasi Pola Ketukan. Universitas Diponegoro, Semarang.

[3] Syauki, Alfi. 2009. Kelangsungan Hidup Benih Bawal Air Tawar Colossamma Macropomum Cuvier Pada Sistem Pengangkutan Tertutup Dengan Padat Penebaran 43, 86 dan 129 Ekor/Liter. Institut Pertanian Bogor, Bogor.

[4]Kristianto, Andrian. 2012. Pengendali pH Air Dengan Menggunakan Metode PID Pada Model Tambak Udang, Universitas Diponegoro Semarang.

[5] Datasheet ATMega16

[6 ]Datasheet ATMega8

[7] Datasheet $L C D 16 \times 2$ 